\title{
Dehydrocorydaline Inhibits Cell Proliferation, Migration and Invasion via Suppressing MEKI/2-ERKI/2 Cascade in Melanoma [Corrigendum]
}

$\mathrm{Hu} \mathrm{H}$, Dong $\mathrm{Z}$, Wang $\mathrm{X}$, et al. Onco Targets Ther. 2019;12:5163-5175.

The authors have advised due to an error at the time of figure assembly, Figures 2G and 4A on pages 5167 and
5169, respectively is incorrect. The correct Figures 2 and 4 are shown below.

The authors apologize for these errors and advise it does not affect the results of the paper.
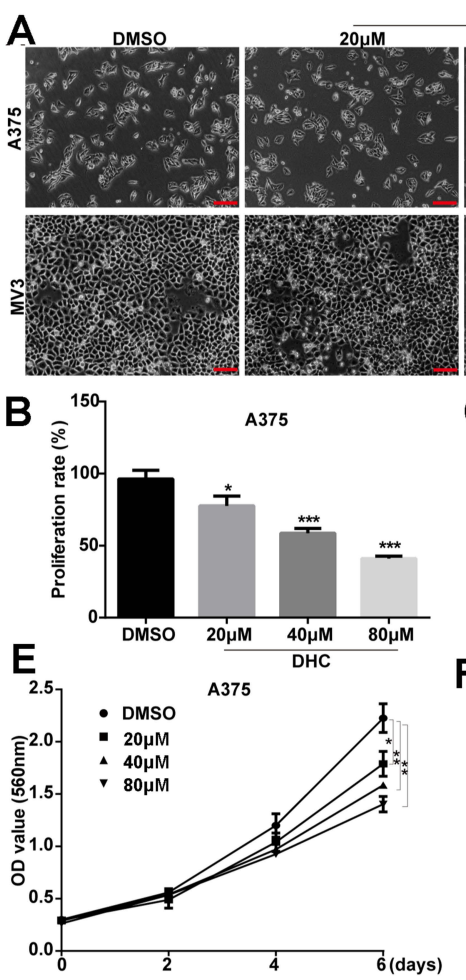
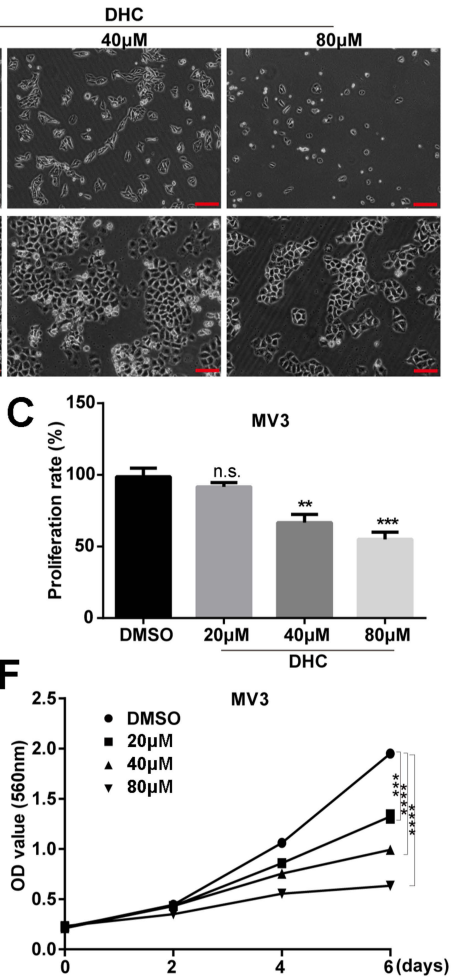
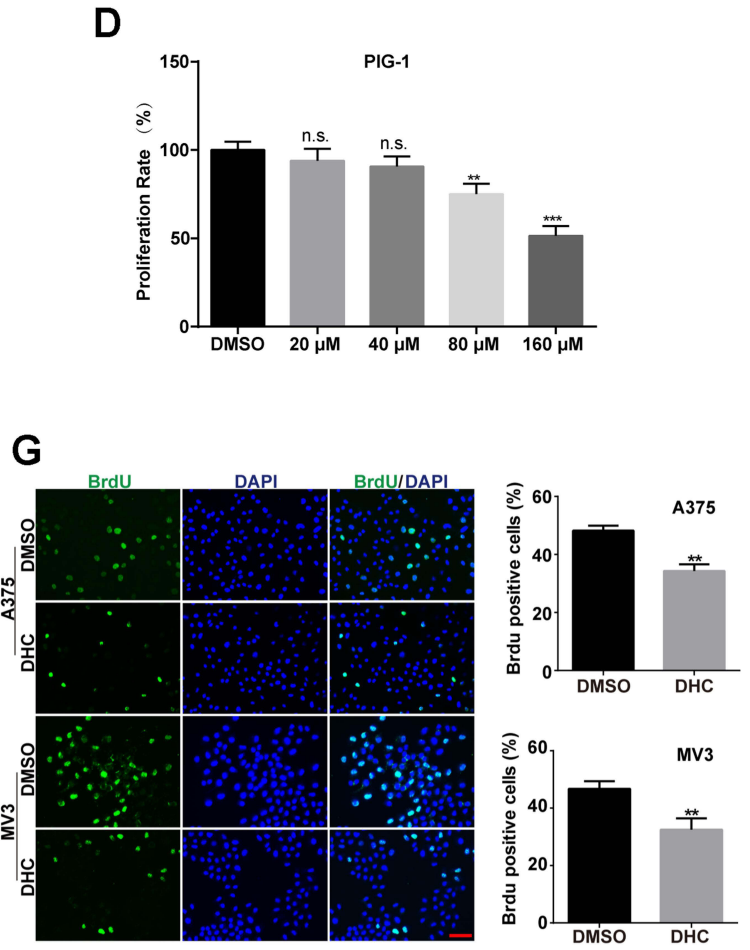

Figure 2 Dehydrocorydaline inhibits cell growth and proliferation in human melanoma cells. (A) Cell morphology of A375 and MV3 melanoma cells after treating with DMSO or the indicated concentrations of DHC for $48 \mathrm{~h}$. Scale bar, $100 \mu \mathrm{m}$. (B and $\mathbf{C}$ ) The effect of DHC on the proliferation rates of A375 and MV3 cells determined by cell counting in the microscope. (D) The effect of different concentrations of DHC treatment for $48 \mathrm{~h}$ on the proliferation rate of PIGI cells determined by MTT assay. (E and $\mathbf{F}$ ) The effect of DHC on the viability of A375 and MV3 cells. (G) Images and quantifications of A375 and MV3 cells positive for BrdU staining after treating with DMSO or $40 \mu \mathrm{M} \mathrm{DHC}$ for $24 \mathrm{~h}$. Scale bar, I00 $\mu \mathrm{m}$. All data are shown as the mean \pm SD. A two-tailed unpaired Student's t-test was carried out. $* p<0.05$, $* * p<0.0$ I, $* * * p<0.00 \mathrm{I}$, $* * * * p<0.0001$.

Abbreviations: DHC, dehydrocorydaline; DMSO, dimethyl sulfoxide; MTT, 3-(4,5-dimethylthiazol-2-yl)-2,5-diphenyl tetrazolium bromide. 

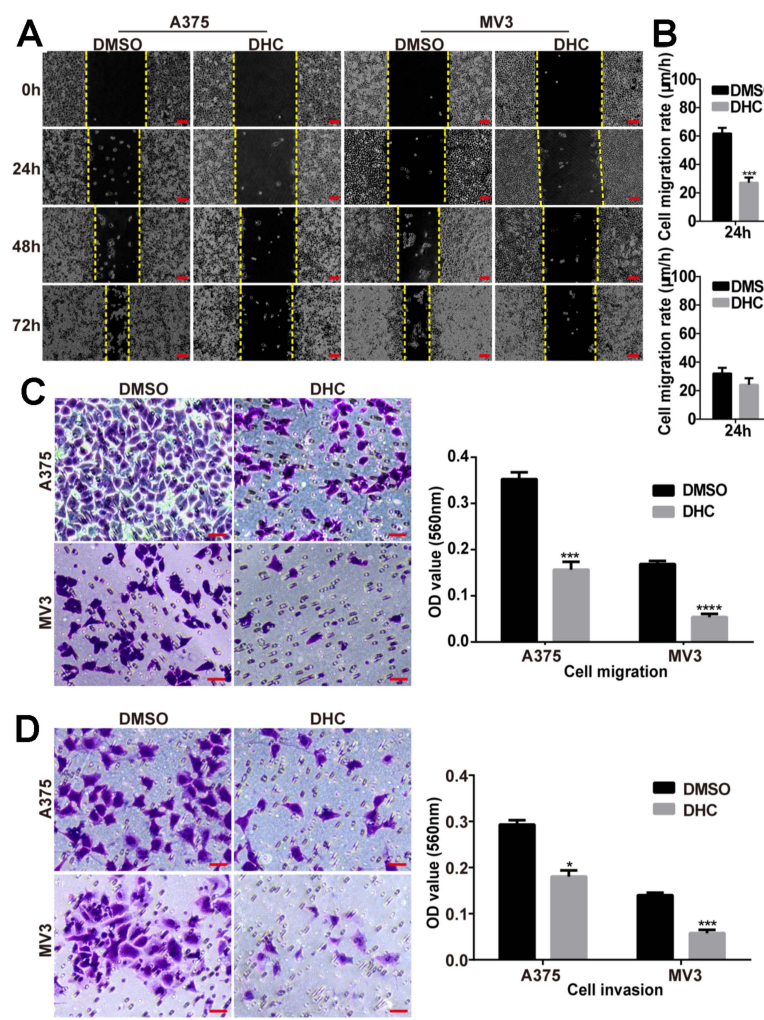
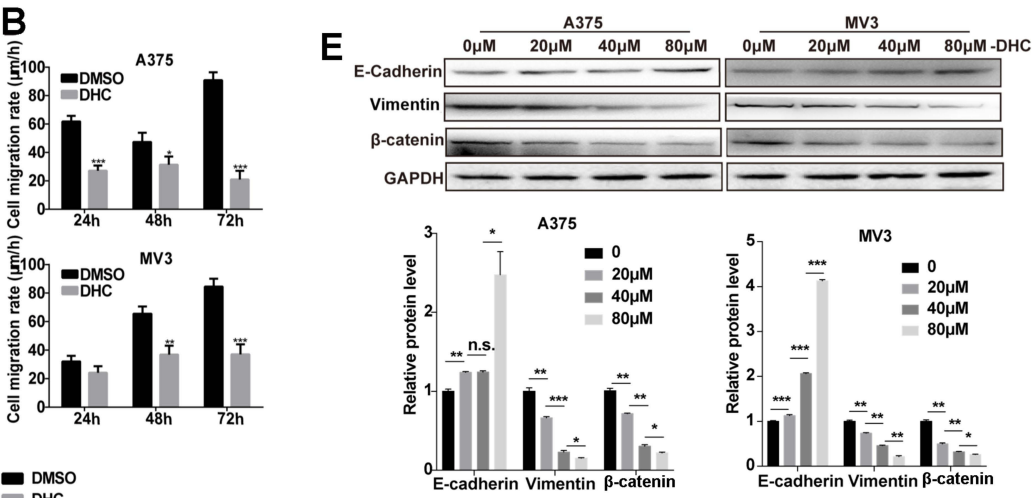

$\mathbf{F}$
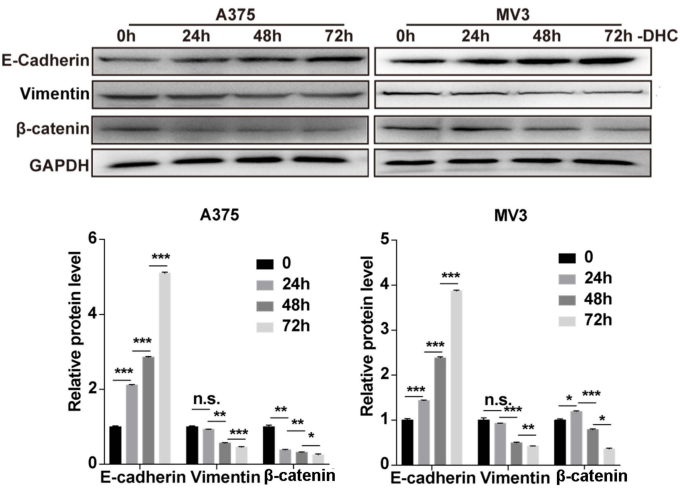

Figure 4 Dehydrocorydaline inhibits cell migration and invasion in melanoma cells. (A) Cell migration rate detected by wound-healing assay of A375 and MV3 cells after treating with DMSO or $40 \mu \mathrm{M}$ DHC for the indicated time. Scale bar, $100 \mu \mathrm{m}$. (B) The effect of $40 \mu \mathrm{M}$ DHC on the wound closure in A375 and MV3 cells. (C) The effect of transwell migration assays in A375 and MV3 cells after treating with DMSO or $40 \mu$ D DHC for 24 h. Scale bar, $100 \mu$ m. Migration rates were normalized by proliferation. (D) The effect of transwell invasion assays in A375 and MV3 cells after treating with DMSO or $40 \mu \mathrm{M}$ DHC for $72 \mathrm{~h}$. Scale bar, I00 $\mu \mathrm{m}$. Invasion rates were normalized by proliferation. (E and F) Western blot analysis of the metastasis-related protein levels in A375 and MV3 cells, respectively. Protein levels were calculated based on the grayscale value of protein bands and normalized with the grayscale value of GAPDH bands. Cells were treated with the indicated concentrations $(0,20,40,80 \mu \mathrm{M})$ of $\mathrm{DHC}$ for $48 \mathrm{~h}$ or with $40 \mu \mathrm{M} \mathrm{DHC}$ treatment for indicated times $(0,24,48,72 \mathrm{~h})$ of DHC; GAPDH was used as a control. All data are shown as the mean \pm SD. A two-tailed unpaired Student's $t$-test was carried out. $*_{p}<0.05$, *** $p<0.01$, $* * * p<0.001$, ***** $p<0.000$ I.

Abbreviations: DHC, dehydrocorydaline; DMSO, dimethyl sulfoxide; GAPDH, glyceraldehyde 3-phosphate dehydrogenase.

\section{Publish your work in this journal}

OncoTargets and Therapy is an international, peer-reviewed, open access journal focusing on the pathological basis of all cancers, potential targets for therapy and treatment protocols employed to improve the management of cancer patients. The journal also focuses on the impact of management programs and new therapeutic agents and protocols on patient perspectives such as quality of life, adherence and satisfaction. The manuscript management system is completely online and includes a very quick and fair peer-review system, which is all easy to use. Visit http://www.dovepress.com/ testimonials.php to read real quotes from published authors. 